Published in final edited form as:

Exp Gerontol. 2016 January ; 73: 95-106. doi:10.1016/j.exger.2015.11.013.

\title{
Acetaminophen hepatotoxicity in mice: Effect of age, frailty and exposure type
}

\author{
Alice E. Kane ${ }^{a, b, c,{ }^{*}, \text { Sarah J. Mitchell }}{ }^{d}$, John Mach ${ }^{a, b, c}$, Aniko Huizer-Pajkos ${ }^{a, b}$, Catriona $^{2}$ \\ McKenzie $^{e}$, Brett Jones ${ }^{a, b, c}$, Victoria Cogger ${ }^{c, f}$, David G. Le Couteurc, ${ }^{c}$, Rafael de Cabo ${ }^{d}$, and \\ Sarah N. Hilmer ${ }^{a, b, c}$ \\ aKolling Institute of Medical Research, Sydney, NSW, Australia

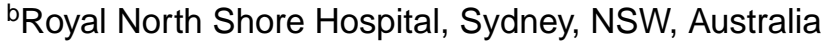 \\ 'Sydney Medical School, University of Sydney, Sydney, NSW, Australia \\ dNational Institute on Aging, Baltimore, MD, USA \\ eRoyal Prince Alfred Hospital, Sydney, NSW, Australia \\ ${ }^{f}$ Centre for Education and Research on Ageing, ANZAC Research Institute, Sydney, NSW, \\ Australia
}

\section{Abstract}

Acetaminophen is a commonly used analgesic that can cause severe hepatotoxicity in overdose. Despite old age and frailty being associated with extensive and long-term utilization of acetaminophen and a high prevalence of adverse drug reactions, there is limited information on the risks of toxicity from acetaminophen in old age and frailty. This study aimed to assess changes in the risk and mechanisms of hepatotoxicity from acute, chronic and sub-acute acetaminophen exposure with old age and frailty in mice. Young and old male C57BL/6 mice were exposed to either acute $(300 \mathrm{mg} / \mathrm{kg}$ via oral gavage), chronic $(100 \mathrm{mg} / \mathrm{kg} / \mathrm{day}$ in diet for six weeks) or subacute $(250 \mathrm{mg} / \mathrm{kg}$, t.i.d., for three days) acetaminophen, or saline control. Pre-dosing mice were scored for the mouse clinical frailty index, and after dosing serum and liver tissue were collected for assessment of toxicity and mechanisms. There were no differences with old age or frailty in the degree of hepatotoxicity induced by acute, chronic or subacute acetaminophen exposure as assessed by serum liver enzymes and histology. Age-related changes in the acetaminophen toxicity pathways included increased liver GSH concentrations, increased NQO1 activity and an increased pro- and anti-inflammatory response to acetaminophen in old age. Frailty-related changes included a negative correlation between frailty index and serum protein, albumin and ALP concentrations for some mouse groups. In conclusion, although there were changes in some pathways that would be expected to influence susceptibility to acetaminophen toxicity, there was no overall increase in acetaminophen hepatotoxicity with old age or frailty in mice.

\section{Keywords}

Acetaminophen; Hepatotoxicity; Ageing; Frailty; Mice; Liver; Paracetamol

\footnotetext{
"Corresponding author at: Laboratory of Ageing and Pharmacology, Level 12, Kolling Building, St Leonards, NSW 2065, Australia.
} 


\section{Introduction}

Acetaminophen is a commonly used analgesic that can cause severe hepatotoxicity in overdose. The pharmacokinetic and toxicological mechanisms of an acute over-exposure to acetaminophen in young adults have been well established (Larson, 2007; Jaeschke et al., 2012). Following an acute overdose of acetaminophen, there is saturation of the conjugation metabolism pathways in the liver, resulting in more drug being oxidized into the toxic metabolite, N-acetyl-p-benzoquinone imine (NAPQI), by the cytochrome P450 (CYP450) enzyme, CYP2E1 (Holt and Ju, 2006). Glutathione (GSH) becomes depleted, resulting in build-up of the toxic metabolite, NAPQI in the liver. NAPQI causes direct mitochondrial damage (Jaeschke, 1990), and the induction of an inflammatory response (Antoine et al., 2008), which can result in cell death, predominantly centrilobular necrosis (Mitchell et al., 1973), with some evidence for apoptosis (Possamai et al., 2013).

With old age, and frailty, pharmacokinetic and pharmacodynamic changes occur that may affect the pharmacology and toxicology of acetaminophen (Mitchell et al., 2011a). Despite the fact that old age and frailty are associated with significant physiological changes, extensive utilization of drugs, including acetaminophen, (Pearson et al., 2007; Koponen et al., 2013), and a high prevalence of adverse drug reactions (Burgess et al., 2005), there are very limited studies on the changing risks of toxicity from acetaminophen in old age and frailty.

A study of hospitalized patients found that frail older people taking therapeutic doses of acetaminophen for five days had higher serum acetaminophen concentrations than younger patients, without increased liver enzymes (Mitchell et al., 2011b). A study of acetaminophen self-poisoning in Denmark, found that although the majority of acetaminophen induced hepatotoxicity occurs in young adults, the majority of deaths associated with acetaminophen exposure occur in old age (Schmidt, 2005). Clinical studies have shown an increased risk of liver failure after staggered over-exposures to acetaminophen (Craig et al., 2012; Ferner et al., 2011). Older people are more likely, than younger people, to have chronic low-dose exposure or accidental overexposure to acetaminophen (Kane et al., 2012). However, the changing risk of toxicity to these types of acetaminophen exposures in old age has not been investigated.

There have been several animal studies, using Fischer 344 rats that have shown a decreased risk of acute acetaminophen hepatotoxicity in old age (Rikans and Moore, 1988), due to a reduction in CYP2E1 activity (Mach et al., 2014) or reduced transfer of acetaminophen into the liver (Mitchell et al., 2011c). Studies in Sprague Dawley rats, however, found an increased susceptibility to hepatotoxicity in old age (Tarloff et al., 1996). This may have been related to higher dosing in old age due to weight-gain in this ageing model (Mach et al., 2014). A recent study suggested that mice are a more clinically relevant model of acetaminophen toxicity than rats, due to similar susceptibility and mechanisms of damage (McGill et al., 2012). The only mouse studies we are aware of on the effect of old age on acetaminophen toxicity, did not investigate direct toxicity outcomes, but did find decreased liver glutathi-one concentrations in old age which may imply increased susceptibility to 
toxicity in old age (Chen et al., 1990; Al-Turk and Stohs, 1981). Here we seek to establish for the first time the risk of acetaminophen toxicity in old age and frailty in mice.

Animal studies on the effect of chronic or sub-acute acetaminophen exposure are limited. Several studies showed that low-dose acetaminophen administered daily did not cause liver toxicity in the absence of other risk factors in young mice (Yisarakun et al., 2014; Kondo et al., 2012; De Meijer et al., 2012). Studies of moderate dose acetaminophen pre-treatment have found it either to protect against (Ghanem et al., 2009; O'Brien et al., 2000; Shayiq et al., 1999), or increase the risk of toxicity (Kim et al., 2009) from further acetaminophen doses. There have been no animal studies on chronic or subacute acetaminophen exposure in old age.

The recent development of frailty assessment tools for animals, allows the study of not only age-related changes, but also frailty-related changes in animals models for the first time. Whitehead et al. (2014) developed and validated a mouse frailty index, which utilizes 31 simply assessed clinical measures to assess frailty in C57BL/6J mice. This tool has not yet been used to investigate changes in drug toxicity with frailty.

Our study aims to assess changes in the risk and mechanisms of hepatotoxicity from acute, chronic and sub-acute acetaminophen exposure with old age and frailty in C57BL/6 mice. Understanding the risk of acetaminophen hepatotoxicity, from different exposure types, and in old age and frailty is important for optimizing the safe effective use of acetaminophen in older people.

\section{Methods}

\subsection{Animals}

Three cohorts of young and old male C57BL/6 mice were used to test the different acetaminophen exposures. Cohort one was made up of young (age $=7.3 \pm 0.3$ months, $\mathrm{n}=$ 23 ) and old (age $=18.9 \pm 2.3$ months, $\mathrm{n}=25)$ male Cre control C57BL/6 transgenic littermates, and C57BL/6 wild-types, aged at the National Institute on Ageing (NIA, Baltimore, MD). Mice were fed a 2018 Teklad Global 18\% Protein Rodent diet (Harlan laboratories). A second cohort of young (age $=10 \pm 0.0$ months, $\mathrm{n}=12$ ) and old (age $=23.7$ \pm 0.02 months, $\mathrm{n}=16$ ) male C57BL/6 mice were also aged at the NIA (Baltimore, MD). They were fed a standard AIN-93G diet (Harlan laboratories). A third cohort of young (age $=4.0 \pm 0.3$ months, $\mathrm{n}=21)$ and old (age $=26.8 \pm 0.5$ months, $\mathrm{n}=17$ ) male C57BL/6 mice were obtained from, and aged at the Kearns Facility (St Leonards, NSW, Australia). Mice were fed a standard Rat and Mouse Premium Breeder Diet (Gordon's Specialty Stockfeeds, NSW, Australia).

All mice were group housed in cages of 4-5 with ad libitum access to food and water. Animal rooms were maintained on a $12 \mathrm{~h} \mathrm{light/dark} \mathrm{cycle} \mathrm{at} 20-22{ }^{\circ} \mathrm{C}$, and $30-70 \%$ humidity. Animals were randomly assigned to treatment or control groups prior to the treatment day. All animal protocols were approved by the Animal Care and Use Committee of the National Institute on Ageing (429-TGB-2017 and 405-TGB-2016) or the Northern Sydney Local Health District Animal Ethics Committee (1206-014A). 


\subsection{Frailty index assessment}

The Mouse Clinical Frailty Index (Whitehead et al., 2014) is a simple, noninvasive tool for the assessment of frailty in mice. A frailty index score is calculated for each mouse using a 31 item frailty index. Old mice from cohort two were assessed for frailty, after randomization to treatment group, the day before being dosed with acetaminophen. Frailty testing was carried out by two raters (AK and SM). Old mice from cohort three were assessed for frailty, after randomization to treatment group, the day before being started on their acetaminophen or control diet. Frailty testing was carried out by two raters (AK and JM). The raters were blinded to each others scores. The final reported frailty index scores were calculated from the mean of the two raters' scores.

\subsection{Acetaminophen treatment and tissue collection}

For cohorts one and two, there were two exposure groups: an acute high dose acetaminophen group and a control group. Animals were fasted overnight (16 h), then dosed with 300 $\mathrm{mg} / \mathrm{kg}$ acetaminophen (Panadol Color-free Baby Drops, $100 \mathrm{mg} / \mathrm{mL}$, GlaxoSmithKline, Australia) (acute group) or saline vehicle (control group) via oral gavage between 8 and 10 am. This paracetamol dose was chosen as a standard dose to induce toxicity in C57BL/6 mice (McGill et al., 2012). Food was returned to the mice $2 \mathrm{~h}$ after dosing. Six hours after dosing mice were anaesthetized with an i.p. injection of ketamine $(75 \mathrm{mg} / \mathrm{kg}$, DVR Pharmacy, Bethesda MD) and xylazine (10 mg/kg, DVR Pharmacy Bethesda MD). A midline laparotomy was performed and blood taken from the Inferior Vena Cava. The portal vein was then cannulated with a $21 \mathrm{G}$ intravenous catheter (BD, Sydney, Australia) through which the liver was perfused in-situ at $1-1.5 \mathrm{~mL} / \mathrm{min} / \mathrm{g}$ of liver with oxygenated KrebsHenseleit bicarbonate buffer $\left(95 \% \mathrm{O}_{2}-5 \% \mathrm{CO}_{2}, 37^{\circ} \mathrm{C}\right)$, to remove blood from the liver. Sections of the liver were snap frozen in liquid nitrogen for subsequent enzyme activity assays, RNA extraction and fixed in 10\% neutral formalin for subsequent histopathological analysis. See Appendix Fig. A.1 for flow chart.

For cohort three, there were three exposure groups: a control group, a chronic acetaminophen group, and a sub-acute acetaminophen group. All mice were randomized to either a control diet (control and sub-acute groups), or control diet supplemented with acetaminophen at a concentration of $1.33 \mathrm{~g} / \mathrm{kg}$ feed (chronic group), both diets fed ad libitum. Mice remained on their respective diets for six weeks (food was weighed every 2 weeks). The sub-acute acetaminophen group was then administered, via oral gavage, acetaminophen (Panadol Color-free Baby Drops, $100 \mathrm{mg} / \mathrm{mL}$, GlaxoSmithKline, Australia), $250 \mathrm{mg} / \mathrm{kg}$ three times per day (at $8 \mathrm{am}, 1 \mathrm{pm}, 6 \mathrm{pm}$ ) for two days. On the third day the mice were fasted at $6 \mathrm{am}$, then gavaged with two more doses of acetaminophen $(250 \mathrm{mg} / \mathrm{kg})$, at 8 am and $1 \mathrm{pm}$. The control diet group and the chronic group, received the same regimen of saline dosing. Three hours after the final acetaminophen or saline dose, all mice were anaesthetized with an i.p. injection of ketamine $(75 \mathrm{mg} / \mathrm{kg}$, Cenvet Australia, \#K1500) and xylazine (10 mg/kg, Cenvet Australia, \#X5010), and blood and liver collected as described above. See Appendix Fig. A.1 for flow chart.

The chronic acetaminophen daily dose was chosen based on a previous study that determined this dose provided analgesia in mice (Minville et al., 2011). Pilot studies were 
conducted in young C57BL/6 mice to determine the minimum sub-acute acetaminophen dose that caused an ALT over three times the upper limit of normal after three days of treatment in 50\% of mice. Six mice fed an acetaminophen-containing diet for six weeks, were treated with either $50 \mathrm{mg} / \mathrm{kg}(\mathrm{n}=2), 100 \mathrm{mg} / \mathrm{kg}(\mathrm{n}=2)$ or $250 \mathrm{mg} / \mathrm{kg}(\mathrm{n}=2)$ acetaminophen via oral gavage three times per day for three days. ALT was only elevated to more than three times the upper limit of normal in one mouse that was dosed $250 \mathrm{mg} / \mathrm{kg}$. Therefore, this dose was chosen to ensure there was sufficient detectable hepatotoxicity.

\subsection{Serum biochemistry to assess liver and renal function}

Blood was stored at $4{ }^{\circ} \mathrm{C}$ for up to $2 \mathrm{~h}$ before separating the serum by centrifugation at $10,000 \mathrm{~g}$ for $10 \mathrm{~min}$. Serum was stored in aliquots at $-80^{\circ} \mathrm{C}$. Serum liver function tests (total protein, albumin, bilirubin, alkaline phosphatase (ALP), gamma glutamyltransferase (GGT)), for all cohorts, and creatinine, for cohort one, were measured by a National Association of Testing Authorities accredited hospital laboratory, PaLMS (Pacific Laboratory Medicine Services) at Royal North Shore Hospital (Sydney, Australia) using an Architect i1000SR immunoassay analyser (Abbott Diagnostics, IL, USA).

\subsection{Liver histology}

Fixed liver tissue was embedded in paraffin, $5 \mu \mathrm{m}$ sections were cut on a microtome and mounted on slides. Slides were stained with Haematoxylin and Eosin in the National Association of Testing Authorities accredited hospital laboratory of the Pathology department of Royal Prince Alfred Hospital, Sydney, Australia. Histopathology was scored by an anatomical pathologist (CM), who was blinded to the age and treatment of the samples.

\subsection{Biochemical examination of enzymes and glutathione in frozen liver samples}

Liver microsomes were isolated, and the CYP2E1 activity measured using absorption of paminophenol, converted from aniline via aniline hydroxylase activity, as described by Roberts et al. (1995) and Mach et al. (2014). NAD(P)H dehydrogenase quinone 1 (NQO1) activity was measured in the liver cytosol according to the method described by Mach et al. (2014). Liver concentrations of total glutathione were determined with a Glutathione Assay kit (Cayman Chemicals, \#703002).

\section{7. mRNA expression measurement of inflammatory mediators with qPCR}

For livers of mice from cohort 1 (acute group) only, RNA was extracted from liver tissue using the TRIzol reagent (Invitrogen, Carlsbad CA), according to the manufacturer's instructions. Briefly, tissue was homogenized in TRIzol reagent. Chloroform was added, the sample centrifuged, and the aqueous phase collected. RNA was precipitated with isopropanol, the sample centrifuged and the supernatant discarded. The RNA pellet was washed with 70\% ethanol then re-dissolved in nuclease-free water, and the concentration determined. Complementary DNA (cDNA) was synthesized from the extracted RNA using a Reverse Transcription Kit (Applied Biosystems, \#4368814) and in a BioRad thermocycler (PTC-200, CA, USA). PCR plates were then loaded in triplicate with sample, appropriate primers and SYBR Green Mastermix (Qiagen \#330523). Plates were run in the 7300 Real- 
Time PCR System (Applied Biosystems). Primers used were for: pro-inflammatory cytokines tumour necrosis factor alpha (TNF- $\alpha$ ) and in-terleukin (IL)-1 $\beta$; anti-inflammatory cytokine IL-10; the cytokine-production regulating protein complex, nuclear factor kappalight-chain-enhancer of activated B cells (NF- $\mathrm{kB}$ ); the apoptosis marker Cas-pase 3; apoptosis promoting protein $\mathrm{BAX}$; and the mitochondrial regulator proteins, peroxisome proliferator-activated receptor gamma coactivator (PGC)1- $\alpha$ and PGC1- $\beta$ (sequences in Appendix Table A.2).

\subsection{Statistics}

Data are expressed as mean \pm SEM unless otherwise indicated. Differences between mean values across groups were calculated with one-way or two-way ANOVA with Tukey's HSD post-hoc test where appropriate. The prevalence of necrosis in each treated group compared to the saline group was compared with Chi squared. The calculation of mRNA expression was performed by the $2-\Delta \Delta \mathrm{CT}$ method. Spearman correlation coefficients were used to analyse the correlation between Frailty Index and other outcomes, and linear regression was used to calculate slopes of best fit for each treatment group. ANCOVA was used to compare the regression slopes between treatment groups, with frailty index as a covariate.

\section{Results}

\subsection{Assessment of acetaminophen toxicity}

Table 1 shows mouse and liver weights, food consumed, serum liver function test and creatinine results, for mouse groups from cohorts 1,2 and 3 . There was no difference across any group, for any cohort of mice, for total protein, albumin, ALP, GGT or liver weight (as percentage of body weight).

All acute acetaminophen treated groups, in cohorts 1 and 2, had increased mean serum ALT (Fig. 1) and increased hepatic necrosis on histology (Appendix Fig. A.1). For cohort 3 mice, chronic acetaminophen treatment resulted in no increase in serum ALT concentration (Fig. 1) in young or old mice. There was, in fact, a slight decrease in serum ALT with chronic acetaminophen treatment in old mice (Fig. 1). Subacute acetaminophen treatment resulted in significantly increased serum ALT concentrations in young mice, but not old mice (Fig. 1). There were no significant differences in the degree of necrosis across any groups for young or old mice from cohort 3 (Appendix Fig. A.1). Two-way ANOVA showed that there was no age effect, nor any age-treatment interaction effect on the degree of hepatotoxicity as measured by serum ALT concentrations or the mean percentage of liver necrosis, in any cohort of mice.

\subsection{Assessment of factors influencing acetaminophen pharmacokinetics}

Activity of microsomal CYP2E1, the enzyme that metabolizes acetaminophen to its hepatotoxic metabolite, NAPQI, was significantly decreased in old cohort 1 (acute group) mice treated with acute high dose acetaminophen, compared to saline control (Fig. 2). There was no significant reduction in CYP2E1 activity with acute high dose acetaminophen in young cohort 1 mice, or in young or old cohort 2 (acute group) mice $(\mathrm{p}=0.10)$. 2-Way ANOVA showed an overall significant effect of treatment but not age for both cohorts 
(cohort $1 \mathrm{p}=0.001$, cohort $2 \mathrm{p}=0.015$ ) (Fig. 2). There was no change in CYP2E1 activity across any treatment group (chronic or sub-acute) for young or old mice from cohort 3 (Fig. 2).

Total liver glutathione, which binds and detoxifies NAPQI, was not significantly reduced with acute high dose acetaminophen treatment in young or old mice in cohort 1 (acute group) ( $\mathrm{p}=0.05$ ) (Fig. 3). For cohort 2 and 3 mice, glutathione was significantly decreased with acute or subacute acetaminophen treatment in both young and old mice (Fig. 3).

Additionally older mice in cohort 2 (acute group) had higher total liver GSH concentrations, than younger mice, for both saline and acetaminophen treated mice, with two-way ANOVA showing a significant effect of both age and treatment individually ( $p<0.001)$, as well as a significant age $\times$ treatment effect $(p=0.036)$. For cohort 3 mice there was no change in total liver glutathione concentrations with chronic acetaminophen treatment for either age group (Fig. 3).

Activity of cytosolic NQO1, which transforms NAPQI back to acetaminophen, was increased with age (young saline $=37.2 \pm 14.1$, old saline $=66.3 \pm 12.6, \mathrm{p}<0.001$ ) but unchanged with acute acetaminophen treatment in cohort 1 (young acetaminophen $=45$. \pm 12.9 , old acetaminophen $=60.53 \pm 26.6, \mathrm{p}>0.05)$ and was not assessed in other cohorts

\section{3. mRNA expression of inflammatory, apoptosis and mitochondrial function markers}

Fig. 4 shows that with acute acetaminophen treatment there is an increase in liver mRNA expression of inflammatory markers, TNF- $\alpha$, IL-1 $\beta$, IL-10 and NF- $\kappa B$ for old, but not young mice $(\mathrm{p}<0.05)$. Two-way ANOVA only identifies a significant age $\times$ treatment interaction effect for TNF- $a(p=0.024)$, with a greater increase in TNF-alpha seen after acute high dose acetaminophen in old than in young mice. There was no change in the ratio of pro-inflammatory to anti-inflammatory cytokine expression (TNF-a/IL-10), for any age or treatment group.

There is no change in apoptosis marker, Caspase 3 mRNA expression with age or acute acetaminophen treatment. BAX mRNA expression is increased in old mice treated with acetaminophen, compared to saline controls, and young mice treated with acetaminophen ( $\mathrm{p}$ < 0.05) (Fig. 5). mRNA expression of mitochondrial regulator protein, PGC1- $\alpha$ does not change with age or treatment, whilst PGC1- $\beta$ mRNA expression is increased in old mice treated with acetaminophen only $(\mathrm{p}=0.013)$. Two-way ANOVA shows a significant age $\times$ treatment interaction effect for BAX and PGC1- $\beta(p=0.027, p=0.023)$, with a greater response to treatment seen in old age.

\subsection{Correlation between frailty and acetaminophen toxicity outcomes}

To assess whether frailty affected the risk or mechanisms of acetaminophen hepatotoxicity, we investigated the correlation between frailty index and associated outcomes, for old mice from cohorts 2 (acute treatment, Fig. 6) and 3 (chronic and sub-acute treatment, Fig. 7).

For the acute treatment model (cohort 2), there was no correlation between frailty and serum ALT, percentage of hepatic necrosis, microsomal CYP2E1 activity, total liver GSH or serum ALP for acetaminophen or saline treated old mice (Fig. 6). There were significant strong 
negative correlations between frailty index and serum total protein $(r=-0.963, p=0.000)$, and between frailty index and serum albumin $(r=-0.871, p=0.011)$ for acetaminophen treated old mice (Fig. 6). An ANCOVA showed no significant difference between the regression slopes for either outcome (serum protein or albumin) for treatment group, when adjusted for frailty index as a covariate.

For the chronic and sub-acute treatment models (cohort 3), there was no correlation between frailty and serum ALT, necrosis liver percentage, microsomal CYP2E1 activity, total liver GSH and serum total protein for saline, chronic acetaminophen or sub-acute acetaminophen treated mice (Fig. 7). There were significant strong negative correlations between frailty index and serum albumin $(\mathrm{r}=-0.80, \mathrm{p}=0.05)$ and frailty index and ALP $(\mathrm{r}=-0.92, \mathrm{p}=$ 0.01), for sub-acute acetaminophen treated old mice only (Fig. 7). An ANCOVA showed no significant difference between the regression slopes for these outcomes (ALP, albumin) for treatment group, when adjusted for frailty index as a covariate.

\section{Discussion}

Despite physiological changes that may affect acetaminophen pharmacokinetics and toxicology in old age and frailty, and an increased prevalence in the use of acetaminophen in old age, there have been few studies exploring the effect of age and frailty on acetaminophen toxicity. This project found that overall there was no change in susceptibility to acute, chronic or subacute acetaminophen exposure with old age or frailty in mice.

The current study, which is the first to look at the effect of age on acetaminophen toxicity in mice, found that there was no effect of age on susceptibility to acute acetaminophen toxicity, as assessed by liver necrosis and serum ALT concentration. This is in contrast to the previous studies of acute acetaminophen hepatotoxicity in rats, demonstrating increased risk in Sprague-Dawley rats with age (Tarloff et al., 1996) and decreased risk in old age in Fischer 344 rats (Rikans and Moore, 1988; Mach et al., 2014). There was no change in CYP2E1 activity in old mice compared to young, from any cohort. Interestingly, in old age, rats have a reduction in CYP2E1 activity (Mach et al., 2014), and this provides one mechanism for the observed interspecies difference in toxicity risk. Recent research has identified mice as a more clinically relevant model of acetaminophen toxicity, due to similar susceptibility to, and mechanisms of, toxicity in mice and humans, but not rats (McGill et al., 2012). This implies that the current finding of no change in hepatotoxicity risk due to acute acetaminophen exposure in old age in mice, may be translatable to humans.

As well as acute acetaminophen exposure, this paper modelled two other clinically relevant acetaminophen exposure situations: chronic use of therapeutic levels of acetaminophen; and sub-acute use of supra-therapeutic doses of paracetamol over three days (to mimic accidental overdose due to confusion with multiple paracetamol containing medications or dose escalation for unrelieved pain), and found no effect of age on susceptibility to acetaminophen toxicity from these exposure types. This finding has particular clinical relevance, as older patients are more likely to have these types of exposures to acetaminophen, rather than acute exposure (Kane et al., 2012). Research confirming these findings in a clinical setting, would enable the optimisation of the use of acetaminophen for 
pain relief in the older population, as a relatively well-tolerated analgesic, with no increased risk of toxicity in old age. The exposure protocols used in the current study contained different acetaminophen doses in order to mimic these clinically relevant exposure types. The studies did not investigate the effect of varying time-frame of exposure to the same acetaminophen dose on hepatotoxicity risk. It would be interesting in a future study to determine if short versus long-term use of a therapeutic and/or supratherapeutic dose of acetaminophen effected hepatotoxicity risk in young or old age.

There were some age-related changes in aspects of the acetaminophen toxicity pathway that may explain the lack of change in toxicity risk with old age, seen in this study. In the acute treatment model (cohort two) only, young mice had significantly lower GSH concentrations than old mice. This result was unexpected as previous animal studies have seen a reduction or no change in total liver GSH concentrations with old age (Mach et al., 2014; Mune et al., 1995; Suh et al., 2004), although none of these studies were in C57BL/6 mice. The maintenance of young levels of total GSH in old age in the current study, may be one reason that no increase in the risk of hepatotoxicity with old age was observed Vogt and Richie (1993) found that a decrease in liver GSH was only seen at 29 months of age in mice, so the old mice in our study may have been too young to have significant decreases in liver GSH concentration, and perhaps an older cohort of mice may have different hepatotoxicity risk as a result of this.

This study found increased basal NQO1 activity in old mice compared to young, as has been seen in other animal studies (Mach et al., 2014; Kamzalov and Sohal, 2004; Chen et al., 1994). Increased NQO1 activity may be a protective mechanism against acetaminophen toxicity, and may explain the lack of increased risk to acetaminophen toxicity in old age in our study.

This study also saw an increased inflammatory response to acute acetaminophen in the old mice compared to the young. Interestingly, this increased response was seen for both proand anti-inflammatory cytokines, with no change in the ratio of pro/anti-inflammatory cytokines, and did not translate into a change in degree of acetaminophen toxicity. This increased inflammatory response in old age is consistent with previous ageing animal studies of inflammatory response to stressors (Starr et al., 2013; Okamura et al., 2012; Tateda et al., 1996; Saito et al., 2003), although the relevance in human studies remains to be determined (Starr and Saito, 2014). The timeframe of our acute toxicity assessment was $6 \mathrm{~h}$, and with a longer time-frame the effects of this age-related increased inflammatory response, on the development of or recovery from acetaminophen toxicity may have been observed.

Another interesting age related acetaminophen effect observed in this study was changes to the mRNA expression concentrations of BAX and PGC1- $\beta$ in old mice, but not young, after acetaminophen treatment. Changes in the expression of PGC1 proteins have been associated with ageing in several studies (Dillon et al., 2012), and studies have seen age-related changes in apoptosis associated proteins (Mach et al., 2015), and increased apoptotic response to other stressors in old age (Turnbull et al., 2004). Although it is difficult to conclude what effect these changes in mRNA expression mean without protein expression and activity assay assessments, an increased apoptotic and mitochondrial biogenesis 
response in old mice compared to young, could contribute to a hepato-protective mechanism.

Overall, these age-related changes in aspects of the acetaminophen toxicity pathway appear to be protective against acetaminophen hepatotoxicity. These changes could provide mechanisms for the lack of an increase in acetaminophen hepatotoxicity risk with old age. It is possible that with a longer time frame, or larger mouse numbers to account for large interindividual variation in old age, old mice may even be protected against acetaminophen hepatotoxicity. In the sub-acute acetaminophen treatment group there was a trend towards this, as serum ALT was not significantly increased in old mice, in contrast to young mice. Future studies should confirm these findings.

This study was the first to investigate the effect of frailty on acetaminophen toxicity in an animal model. There was no overall effect of frailty on the degree of acetaminophen toxicity from acute, chronic or sub-acute exposure, as assessed with serum ALT and prevalence of necrosis. The lack of correlation between frailty index and microsomal CYP2E1 activity or total liver GSH provides a mechanism for this finding. However, as we had small numbers of old mice in each group, we may not have been able to completely assess the potential correlation between frailty index and toxicity outcomes. A future study using larger groups of old mice, with a broader spread of frailty indices, would provide clearer understanding of the correlation between frailty and toxicity outcomes. The single clinical study on acetaminophen exposure in frailty, suggested that with exposure to therapeutic doses of acetaminophen, frailer older patients may have been less at risk of toxicity (Mitchell et al., 2011b). Although, this initial finding implies that it is safe to use similar doses of acetaminophen in frail, older patients, as in young, further research is needed to clarify the effect of frailty on acetaminophen toxicity clinically, in order to optimize pain treatment in these patients.

There was a significant correlation of frailty index with serum protein and albumin concentrations in the acute acetaminophen treated old mice of cohort two, but not the saline treated. However, an ANCOVA showed no difference in the regression slopes for these two groups. For cohort three mice there was a significant correlation of frailty index with serum ALP and albumin concentrations in the sub-acute acetaminophen treated mice, but not the saline or chronic acetaminophen treated. However, an ANCOVA also showed no difference in the regression slopes for these three treatment groups. Thus it is hard to conclude whether these findings are an effect of frailty on these outcomes with acetaminophen treatment, or simply an effect of frailty. Several clinical studies have identified low albumin serum concentrations as potential frailty biomarkers (Schalk et al., 2004; Kitamura et al., 2012).

A clear limitation of this study is the use of three separate cohorts of mice with some baseline differences (diet, weights, ages), and the fact that data was not collected on all outcomes for each cohort. Furthermore, the control vehicle, saline, lacked the other components (saccharin sodium, methyl hydroxybenzoate and propyl hydroxybenzoate) of the 'Panadol Baby Drops', used for paracetamol treatment. However, as the majority of the 'Baby Drops' vehicle is saline, and the non-saline ingredients are flavour and preservative components at low concentrations that are not known to cause toxicity, this is unlikely to 
influence the results. Strengths include the novelty of being the first study to investigate the effect of frailty on acetaminophen toxicity, the effect of age on acetaminophen toxicity in the clinically relevant model of ageing mice, and the changes in susceptibility to acetaminophen hepatotoxicity in old age with clinically relevant subacute and chronic acetaminophen exposures, and the quality of our data, with the use of validated assays to assess enzyme activities, qPCR to assess mRNA expression and the use of the novel validated mouse clinical frailty index.

Overall, this study found that there is no difference in the degree of hepatotoxicity induced by acute, subacute or chronic acetaminophen exposure in old age or frailty in mice. There were some age related changes in the acetaminophen toxicity mechanistic pathway including potentially protective increased liver GSH concentrations in one mouse cohort, potentially protective increased NQO1 activity, an increased pro and anti-inflammatory response to acetaminophen with uncertain impact and potentially protective increased mRNA expression of BAX and PGC1- $\beta$ with acetaminophen treatment in old age. However, none of these changes translated into detectable changes in risk of hepatotoxicity, in the time-frame of these experiments. Frailty related changes included a negative correlation between frailty index and serum protein, albumin and ALP concentrations for some mouse groups.

\title{
Supplementary Material
}

Refer to Web version on PubMed Central for supplementary material.

\section{Acknowledgments}

\author{
Funding \\ SJM and RdC are supported by the Intramural Research Program of the National Institute on Ageing, National \\ Institutes of Health. \\ AEK is supported by a National Health and Medical Research Council (NHMRC) biomedical postgraduate \\ scholarship. \\ This project was partly funded by an Australian Association of Gerontology RM Gibson Scientific Research Grant \\ and by the Penney Ageing Research Unit, Royal North Shore Hospital.
}

\section{References}

Al-Turk WA, Stohs SJ. Hepatic glutathione content and aryl hydrocarbon hydroxylase activity of acetaminophen-treated mice as a function of age. Drug Chem Toxicol. 1981; 4:37-48. [PubMed: 7261945]

Antoine DJ, Williams DP, Park BK. Understanding the role of reactive metabolites in drug-induced hepatotoxicity: state of the science. Expert Opin Drug Metab Toxicol. 2008; 4:1415-1427. http:// dx.doi.org/10.1517/17425255.4.11.1415. [PubMed: 18950283]

Burgess CL, Holman CDJ, Satti AG. Adverse drug reactions in older Australians, 1981-2002. Med J Aust. 2005; 182:267-270. [PubMed: 15777140]

Chen TS, Richie JP, Lang CA. Life span profiles of glutathione and acetaminophen detoxification. Drug Metab Dispos. 1990; 18:882-887. [PubMed: 1981532]

Chen LH, Hu N, Snyder DL. Liver DT-diaphorase activity increases with age and dietary restriction in Lobund-Wistar rats. Age. 1994; 17:65-70. http://dx.doi.org/10.1007/BF02434896.

Craig DGN, Bates CM, Davidson JS, Martin KG, Hayes PC, Simpson KJ. Staggered overdose pattern and delay to hospital presentation are associated with adverse outcomes following paracetamol- 
induced hepatotoxicity. Br J Clin Pharmacol. 2012; 73:285-294. http://dx.doi.org/10.1111/j. 1365-2125.2011.04067.x. [PubMed: 22106945]

De Meijer VE, Kalish BT, Meisel JA, Le HD, Puder M. Dietary fish oil aggravates paracetamolinduced liver injury in mice. J Parenter Enter Nutr. 2012; 37:268-273. http://dx.doi.org/ 10.1177/0148607112450735.

Dillon LM, Rebelo AP, Moraes CT. The role of PGC-1 coactivators in aging skeletal muscle and heart. Life. 2012; 64:231-241. http://dx.doi.org/10.1002/iub.608. [PubMed: 22279035]

Ferner R, Dear J, Bateman D. Management of paracetamol poisoning. BMJ. 2011; 342:d2218. http:// dx.doi.org/10.1016/S0165-6147(03)00053-1. [PubMed: 21508044]

Ghanem CI, Ruiz ML, Villanueva SSM, Luquita M, Llesuy S, Catania VA, et al. Effect of repeated administration with subtoxic doses of acetaminophen to rats on enterohepatic recirculation of a subsequent toxic dose. Biochem Pharmacol. 2009; 77:1621-1628. http://dx.doi.org/10.1016/j.bcp. 2009.02.006. [PubMed: 19426699]

Holt MP, Ju C. Mechanisms of drug-induced liver injury. AAPS J. 2006; 8:E48-E54. http://dx.doi.org/ 10.1208/aapsj080106. [PubMed: 16584133]

Jaeschke H. Glutathione disulfide formation and oxidant stress during acetaminophen-induced hepatotoxicity in mice in vivo: the protective effect of allopurinol. J Pharmacol Exp Ther. 1990; 255:935-941. [PubMed: 2262912]

Jaeschke H, McGill MR, Ramachandran A. Oxidant stress, mitochondria, and cell death mechanisms in drug-induced liver injury: lessons learned from acetaminophen hepatotoxicity. Drug Metab Rev. 2012; 44:88-106. http://dx.doi.org/10.3109/03602532.2011.602688. [PubMed: 22229890]

Kamzalov S, Sohal RS. Effect of age and caloric restriction on coenzyme Q and alpha-tocopherol levels in the rat. Exp Gerontol. 2004; 39:1199-1205. http://dx.doi.org/10.1016/j.exger. 2004.04.007. [PubMed: 15288694]

Kane A, Mitchell SJ, Carroll PR, Matthews S, Hilmer SN. Characteristics of older and younger patients with suspected paracetamol toxicity. Australas J Ageing. 2012; 31:190-193. http:// dx.doi.org/10.1111/j.1741-6612.2012.00598.x. [PubMed: 22950592]

Kim SJ, Lee MY, Kwon DY, Kim SY, Kim YC. Alteration in metabolism and toxicity of acetaminophen upon repeated administration in rats. J Pharmacol Sci. 2009; 111:175-181. http:// dx.doi.org/10.1254/jphs.09151FP. [PubMed: 19834287]

Kitamura K, Nakamura K, Nishiwaki T, Ueno K, Nakazawa A, Hasegawa M. Determination of whether the association between serum albumin and activities of daily living in frail elderly people is causal. Environ Health Prev Med. 2012; 17:164-168. http://dx.doi.org/10.1007/ s12199-011-0233-y. [PubMed: 21861116]

Kondo K, Yamada N, Suzuki Y, Toyoda K, Hashimoto T, Takahashi A, et al. Enhancement of acetaminophen-induced chronic hepatotoxicity in restricted fed rats: a nonclinical approach to acetaminophen-induced chronic hepatotoxicity in susceptible patients. J Toxicol Sci. 2012; 37:911-929. [PubMed: 23038001]

Koponen MPH, Bell JS, Karttunen NM, Nykänen IA, Desplenter FAM, Hartikainen SA. Analgesic use and frailty among community-dwelling older people: a population-based study. Drugs Aging. 2013; 30:129-136. http://dx.doi.org/10.1007/s40266-012-0046-8. [PubMed: 23288603]

Larson AM. Acetaminophen hepatotoxicity. Clin Liver Dis. 2007; 11:525-548. http://dx.doi.org/ 10.1016/j.cld.2007.06.006. [PubMed: 17723918]

Mach J, Huizer-Pajkos A, Cogger VC, McKenzie C, Le Couteur DG, Jones BE, et al. The effect of aging on acetaminophen pharmacokinetics, toxicity and Nrf2 in Fi-scher 344 rats. J Gerontol Ser A Biol Sci Med Sci. 2014; 69:387-397. http://dx.doi.org/10.1093/gerona/glt095. [PubMed: 23863315]

Mach J, Huizer-Pajkos A, Kane A, Jones B, McKenzie C, Mitchell SJS, et al. The effect of aging on mitochondrial and cytosolic hepatic intrinsic death pathway and apoptosis associated proteins in Fischer 344 rats. Exp Gerontol. 2015; 67:54-61. http://dx.doi.org/10.1016/j.exger.2015.04.009. [PubMed: 25910621]

McGill MR, Williams CD, Xie Y, Ramachandran A, Jaeschke H. Acetaminophen-induced liver injury in rats and mice: comparison of protein adducts, mitochondrial dysfunction, and oxidative stress in 
the mechanism of toxicity. Toxicol Appl Pharmacol. 2012; 264:387-394. S0041-008X(12)00357-2 [pii]\r. DOI: 10.1016/j.taap.2012.08.015 [PubMed: 22980195]

Minville V, Fourcade O, Mazoit JX, Girolami JP, Tack I. Ondansetron does not block paracetamolinduced analgesia in a mouse model of fracture pain. Br J Anaesth. 2011; 106:112-118. http:// dx.doi.org/10.1093/bja/aeq277. [PubMed: 20952763]

Mitchell J, Jollow D, Potter W, Gillette J, Brodie B. Acetaminophen-induced hepatic necrosis IV. Protective role of glutathione. J Pharmacol Exp Ther. 1973; 187:211-217. [PubMed: 4746329]

Mitchell SJ, Kane AE, Hilmer SN. Age-related changes in the hepatic pharmacology and toxicology of paracetamol. Curr Gerontol Geriatr Res. 2011a; 2011:14. http://dx.doi.org/10.1155/2011/624156.

Mitchell SJ, Hilmer SN, Murnion BP, Matthews S. Hepatotoxicity of therapeutic short-course paracetamol in hospital inpatients: impact of ageing and frailty. J Clin Pharm Ther. 2011b; 36:327335. http://dx.doi.org/10.1111/j.1365-2710.2010.01193.x. [PubMed: 21545612]

Mitchell SJ, Huizer-Pajkos A, Cogger VC, McLachlan AJ, Le Couteur DG, Jones B, et al. Age-related pseudocapillarization of the liver sinusoidal endothelium impairs the hepatic clearance of acetaminophen in rats. J Gerontol Ser A Biol Sci Med Sci. 2011c; 66:400-408. http://dx.doi.org/ 10.1093/gerona/glq221. [PubMed: 21300741]

Mune M, Meydani M, Jahngen-Hodge J, Martin A, Smith D, Palmer V, et al. Effect of calorie restriction on liver and kidney glutathione in aging emory mice. Age. 1995; 18:43-49. http:// dx.doi.org/10.1007/BF02432518.

O’Brien PJ, Slaughter MR, Swain A, Birmingham JM, Greenhill RW, Elcock F, et al. Repeated acetaminophen dosing in rats: adaptation of hepatic anti-oxidant system. Hum Exp Toxicol. 2000; 19:277-283. http://dx.doi.org/10.1191/096032700678815918. [PubMed: 10918522]

Okamura D, Starr ME, Lee EY, Stromberg AJ, Evers BM, Saito H. Age-dependent vulnerability to experimental acute pancreatitis is associated with increased systemic inflammation and thrombosis. Aging Cell. 2012; 11:760-769. http://dx.doi.org/10.1111/j.1474-9726.2012.00841.x. [PubMed: 22672542]

Pearson SA, Ringland C, Kelman C, Mant A, Lowinger J, Stark H, et al. Patterns of analgesic and antiinflammatory medicine use by Australian veterans. Intern Med J. 2007; 37:798-805. http:// dx.doi.org/10.1111/j.1445-5994.2007.01516.x. [PubMed: 18028081]

Possamai LA, Mcphail MJW, Quaglia A, Zingarelli V, Abeles RD, Tidswell R, et al. Character and temporal evolution of apoptosis in acetaminophen-induced acute liver failure. Crit Care Med. 2013; 41:2543-2550. http://dx.doi.org/10.1097/CCM.0b013e31829791a2.Character. [PubMed: 23949472]

Rikans LE, Moore DR. Acetaminophen hepatotoxicity in aging rats. Drug Chem Toxicol. 1988; 11:237-247. [PubMed: 3181038]

Roberts BJ, Shoaf SE, Song BJ. Rapid changes in cytochrome P4502E1 (CYP2E1) activity and other P450 isozymes following ethanol withdrawal in rats. Biochem Pharmacol. 1995; 49:1665-1673. http://dx.doi.org/10.1016/0006-2952(95)00098-K. [PubMed: 7786308]

Saito H, Sherwood E, Varma T, Evers B. Effects of aging on mortality, hypothermia, and cytokine induction in mice with endotoxemia or sepsis. Mech Ageing Dev. 2003; 124:1047-1058. [PubMed: 14659593]

Schalk BWM, Visser M, Deeg DJH, Bouter LM. Lower levels of serum albumin and total cholesterol and future decline in functional performance in older persons: the Longitudinal Aging Study Amsterdam. Age Ageing. 2004; 33:266-272. http://dx.doi.org/10.1093/ageing/afh073. [PubMed: 15082432]

Schmidt LE. Age and paracetamol self-poisoning. Gut. 2005; 54:686-690. http://dx.doi.org/10.1136/ gut.2004.054619. [PubMed: 15831917]

Shayiq RM, Roberts DW, Rothstein K, Snawder JE, Benson W, Ma X, et al. Repeat exposure to incremental doses of acetaminophen provides protection against acetaminophen-induced lethality in mice: an explanation for high acetaminophen dosage in humans without hepatic injury. Hepatology. 1999; 29:451-463. http://dx.doi.org/10.1002/hep.510290241. [PubMed: 9918922]

Starr ME, Saito H. Sepsis in old age: review of human and animal studies. Aging Dis. 2014; 5:126136. http://dx.doi.org/10.14336/AD.2014.0500126. [PubMed: 24729938] 
Starr ME, Hu Y, Stromberg AJ, Carmical JR, Wood TG, Evers BM, et al. Gene expression profile of mouse white adipose tissue during inflammatory stress: age-dependent upregulation of major procoagulant factors. Aging Cell. 2013; 12:194-206. http://dx.doi.org/10.1111/acel.12040. [PubMed: 23279636]

Suh JH, Shenvi SV, Dixon BM, Liu H, Jaiswal AK, Liu RM, et al. Decline in transcriptional activity of Nrf2 causes age-related loss of glutathione synthesis, which is reversible with lipoic acid. Proc Natl Acad Sci U S A. 2004; 101:3381-3386. http://dx.doi.org/10.1073/pnas.0400282101. [PubMed: 14985508]

Tarloff JB, Khairallah EA, Cohen SD, Goldstein RS. Sex- and age-dependent acetaminophen hepatoand nephrotoxicity in Sprague-Dawley rats: role of tissue accumulation, nonprotein sulfhydryl depletion, and covalent binding. Fundam Appl Toxicol. 1996; 30:13-22. [PubMed: 8812206]

Tateda K, Matsumoto T, Miyazaki S, Yamaguchi K. Lipopolysaccharide-induced lethality and cytokine production in aged mice. Infect Immun. 1996; 64:769-774. [PubMed: 8641780]

Turnbull IR, Buchman TG, Javadi P, Woolsey CA, Hotchkiss RS, Karl IE, et al. Age disproportionately increases sepsis-induced apoptosis in the spleen and gut epithelium. Shock. 2004; 22:364-368. http://dx.doi.org/10.1097/01.shk.0000142552.77473.7d. [PubMed: 15377893]

Vogt BL, Richie JP. Fasting-induced depletion of glutathione in the aging mouse. Biochem Pharmacol. 1993; 46:257-263. http://dx.doi.org/10.1016/0006-2952(93)90412-P. [PubMed: 8347148]

Whitehead JC, Hildebrand BA, Sun M, Rockwood MR, Rose RA, Rockwood K, et al. A clinical frailty index in aging mice: comparisons with frailty index data in humans. J Gerontol Biol Sci Med Sci. 2014; 69:621-632. http://dx.doi.org/10.1093/gerona/glt136.

Yisarakun W, Supornsilpchai W, Chantong C, Srikiatkhachorn A, Maneesri-le GS. Chronic paracetamol treatment increases alterations in cerebral vessels in cortical spreading depression model. Microvasc Res. 2014; 94:36-46. http://dx.doi.org/10.1016/j.mvr.2014.04.012. [PubMed: 24819686]

\section{Appendix A}
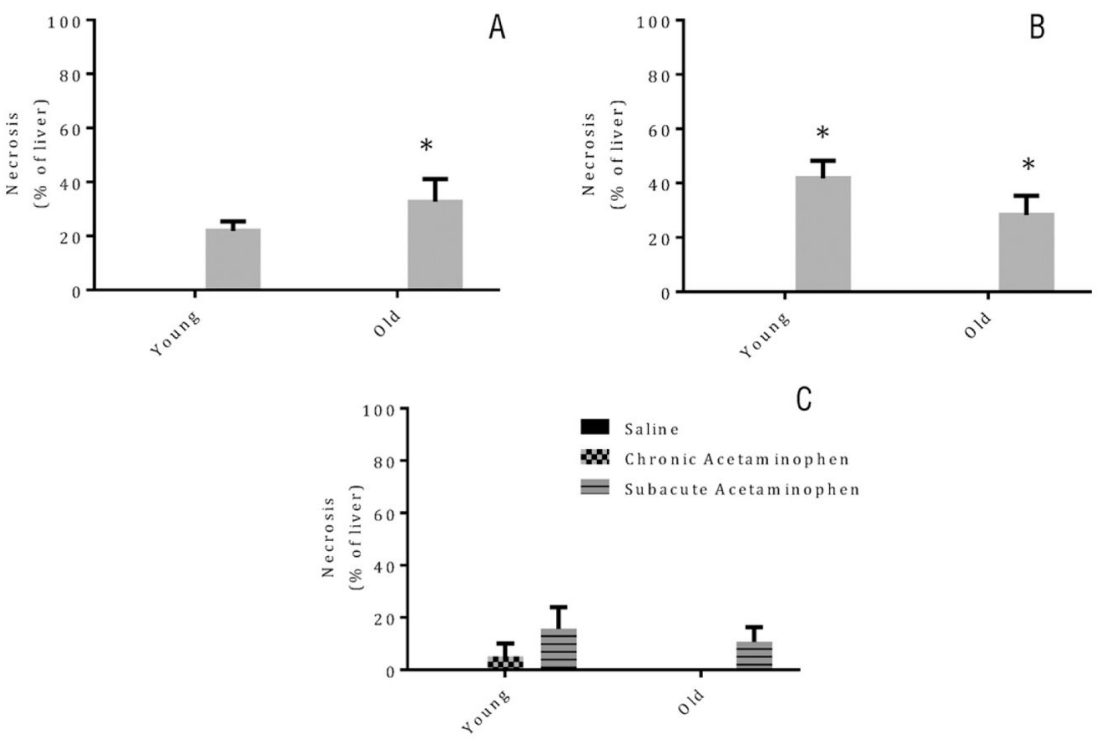

Fig. A.1.

Liver necrosis for young and old male C57BL/6 mice from cohort 1 (A) or cohort 2 (B), $6 \mathrm{~h}$ after treatment with $300 \mathrm{mg} / \mathrm{kg}$ acetaminophen (grey bars) or saline (black bars), and cohort 3 (C) after treatment with either saline (black bars), 6 weeks of dietary chronic acetaminophen (checked grey bars) or 3 days of subacute acetaminophen dosing (striped 
grey bars). Data expressed as mean \pm SEM. $*=p<0.05$ compared to corresponding saline treated group.

Table A.1

Flow chart of acetaminophen treatment for different mouse cohorts and groups.

\begin{tabular}{|c|c|c|c|c|c|c|c|}
\hline \multirow{2}{*}{$\begin{array}{l}\text { Cohorts } 1 \text { and } \\
2 \text { - Acute } \\
\text { acetaminophen } \\
\text { exposure }\end{array}$} & Control group & \multirow{2}{*}{$\begin{array}{l}\text { Young } \\
\text { and old } \\
\text { mice } \\
\text { obtained/ } \\
\text { aged, fed } \\
\text { control } \\
\text { diet }\end{array}$} & \multirow[t]{2}{*}{$\begin{array}{l}\text { Mice fasted, } \\
16 \mathrm{~h}\end{array}$} & $\begin{array}{c}\text { Single dose } \\
\text { acetaminophen } \\
(300 \mathrm{mg} / \mathrm{kg})\end{array}$ & \multirow{2}{*}{\multicolumn{3}{|c|}{$\begin{array}{l}6 \mathrm{~h} \text { later, mice euthanised, liver and } \\
\text { blood collected }\end{array}$}} \\
\hline & Acute group & & & Saline treatment & & & \\
\hline \multirow{3}{*}{$\begin{array}{l}\text { Cohort } 3- \\
\text { Chronic and } \\
\text { subacute } \\
\text { acetaminophen } \\
\text { exposure }\end{array}$} & Control group & \multirow{3}{*}{$\begin{array}{c}\text { Young } \\
\text { and old } \\
\text { mice } \\
\text { obtained/ } \\
\text { aged, fed } \\
\text { control } \\
\text { diet }\end{array}$} & \multirow{2}{*}{$\begin{array}{l}6 \text { weeks, } \\
\text { control diet }\end{array}$} & $\begin{array}{c}\text { Saline } \\
\text { treatment, } 3 \\
\text { times per day } \\
\text { for } 2 \text { days }\end{array}$ & \multirow{3}{*}{$\begin{array}{l}6 \text { am, } \\
\text { mice } \\
\text { fasted }\end{array}$} & $\begin{array}{c}\text { Saline } \\
\text { treatment, } 2 \\
\text { times }\end{array}$ & \multirow{3}{*}{$\begin{array}{l}3 \mathrm{~h} \text { post } \\
\text { final dose, } \\
\text { mice } \\
\text { euthanised, } \\
\text { liver and } \\
\text { blood } \\
\text { collected }\end{array}$} \\
\hline & Subacute group & & & $\begin{array}{c}\text { Sub-acute } \\
\text { acetaminophen, } \\
3 \text { times per day } \\
(250 \mathrm{mg} / \mathrm{kg}) \text { for } \\
2 \text { days }\end{array}$ & & $\begin{array}{c}\text { Sub-acute } \\
\text { acetaminophen, } \\
2 \text { times }\end{array}$ & \\
\hline & Chronic group & & $\begin{array}{c}6 \text { weeks, } \\
\text { acetaminophen } \\
\text { diet }(1.33 \\
\mathrm{mg} / \mathrm{kg} \text { feed })\end{array}$ & $\begin{array}{c}\text { Saline } \\
\text { treatment, } 3 \\
\text { times per day } \\
\text { for } 2 \text { days }\end{array}$ & & $\begin{array}{c}\text { Saline } \\
\text { treatment, } 2 \\
\text { times }\end{array}$ & \\
\hline
\end{tabular}

Table A.2

Primer sequences for $\mathrm{qPCR}$.

\begin{tabular}{lll}
\hline & Forward & Reverse \\
\hline TNF-a & $5^{\prime}$-TAC TGA ACT TCG GGG TGA TTG GTC C-3 & $\begin{array}{l}5^{\prime} \text {-CAG CCT TGT CCC TTG AAG AGA } \\
\text { ACC-3' }\end{array}$ \\
IL-1 $\beta$ & $5^{\prime}$-CTG TGG CAG CTA CCT GTG TC-3' & $5^{\prime}$-GTC ACA GAG GAT GGG CTC TT-3' \\
IL-10 & $5^{\prime}$-GCA ACT GTT CCT GAA CTC AAC T-3' & $5^{\prime}$-ATC TTT TGG GGT CCG TCA ACT-3' \\
NF- $\kappa$ B & $5^{\prime}$-CCT CTG GCG AAT GGC TTT AC-3' & $5^{\prime}$-GCT ATG GAT ACT GCG GTC TGG-3' \\
Caspase 3 & $5^{\prime}$-TGA CTG GAA AGC CGA AAC TC-3' & $5^{\prime}$-ATC TTC TGG CAA GCC ATC TC-3' \\
BAX & $5^{\prime}$-CAA GAA GCT GAG CGA GTG TCT-3' & $5^{\prime}$-GTG TCC ACG TCA GCA ATC AT-3' \\
PGC-1a & $5^{\prime}$-CCT GGC CGA GTT CTT TGA A-3' & $5^{\prime}$-GCC AGA TTT GCT TGT TTG G-3' \\
PGC-1 $\beta$ & $5^{\prime}$-TGG AAA GCC CCT GTG AGA GT-3' & $5^{\prime}$-TTG TAT GGA GGT GTG GTG GG-3' \\
\hline
\end{tabular}



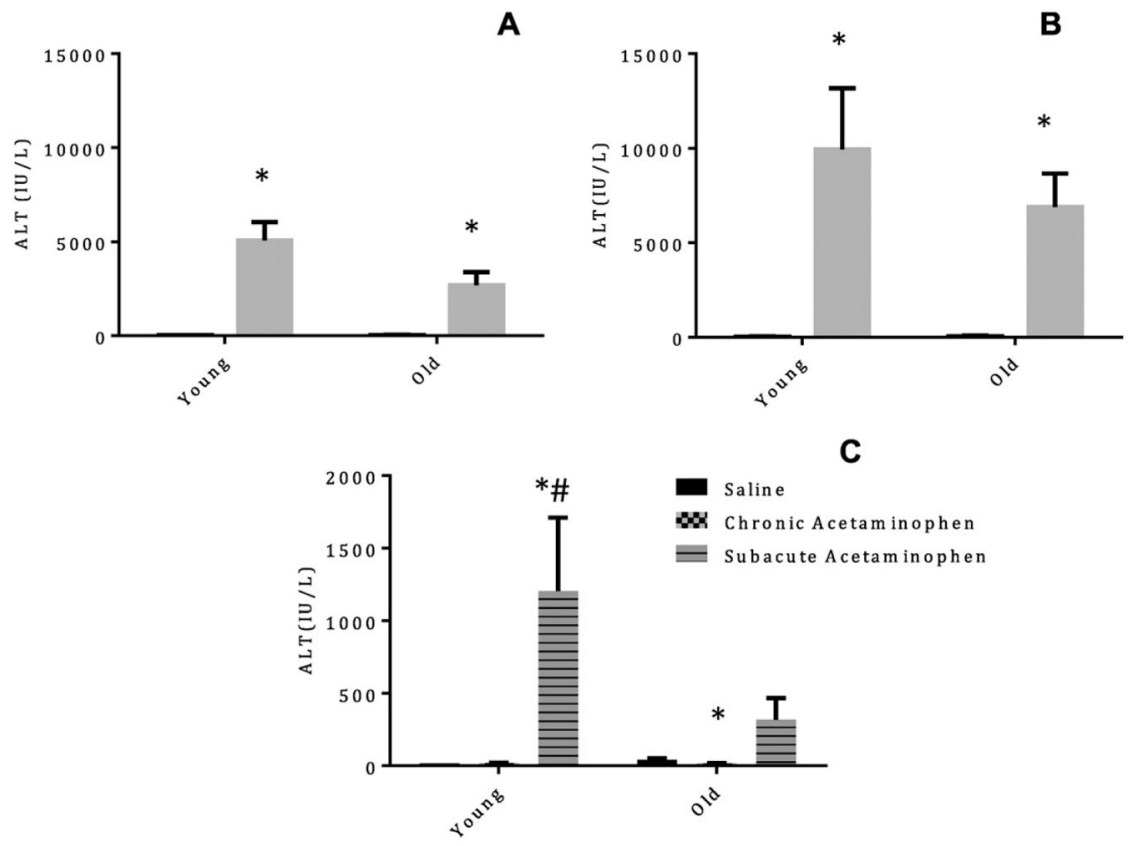

Fig. 1.

Serum alanine aminotransferase (ALT) concentrations for young and old male C57BL/6 mice from cohort 1 (A) and cohort 2 (B), $6 \mathrm{~h}$ after treatment with $300 \mathrm{mg} / \mathrm{kg}$ acetaminophen (grey bars) or saline (black bars) and cohort 3 (C) after treatment with either saline (black bars), 6 weeks of dietary chronic acetaminophen (checked grey bars) or 3 days of subacute acetaminophen dosing (striped grey bars). Data expressed as mean \pm SEM. $*=p<0.05$ compared to corresponding saline treated group. $\#=\mathrm{p}<0.05$ compared to age-matched chronic treated group. 

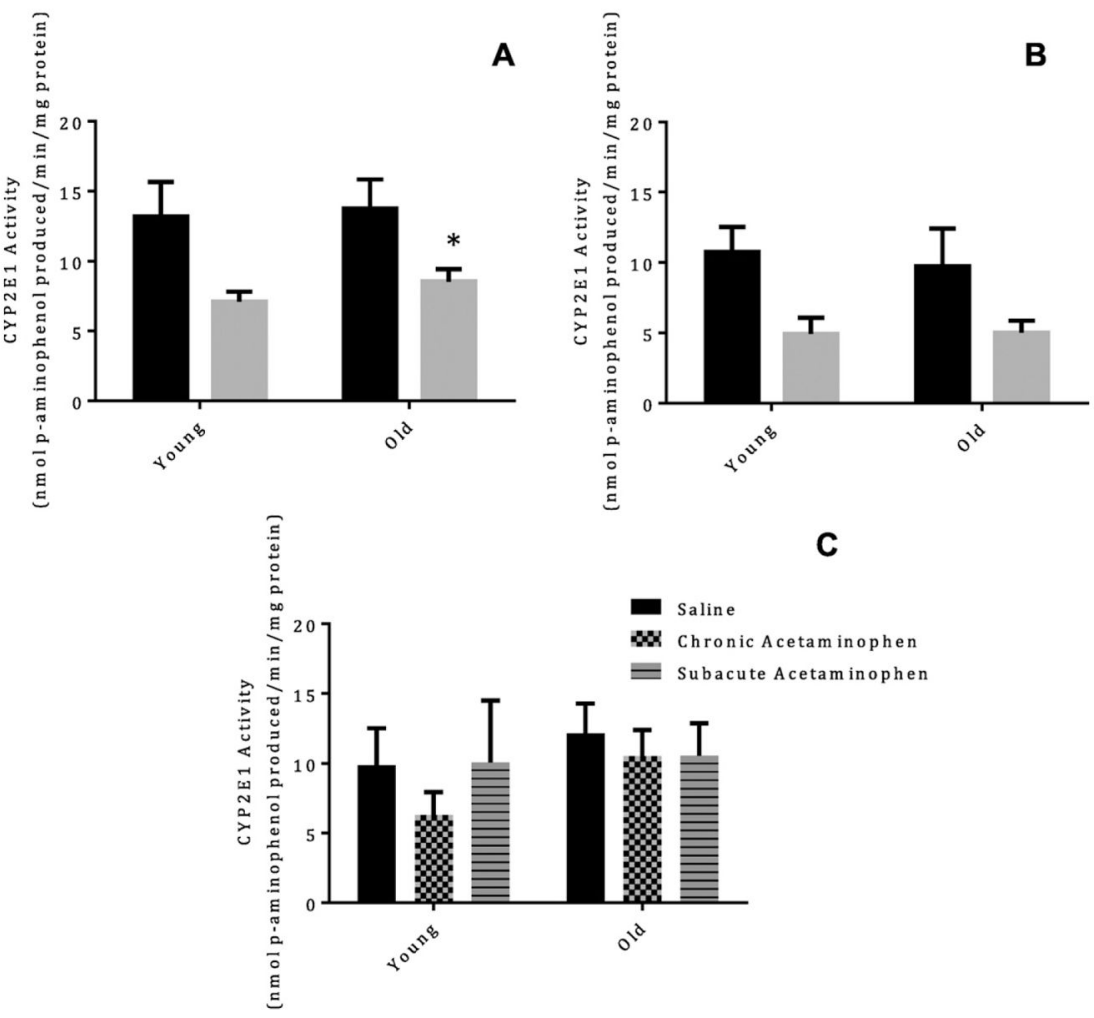

C

Fig. 2.

Cytochrome (CYP)2E1 activity in the livers of young and old male C57BL/6 mice from cohort 1 (A) or cohort 2 (B), $6 \mathrm{~h}$ after treatment with $300 \mathrm{mg} / \mathrm{kg}$ acetaminophen (grey bars) or saline (black bars), and cohort 3 (C) after treatment with either saline (black bars), 6 weeks of dietary chronic acetaminophen (checked grey bars) or 3 days of subacute acetaminophen dosing (striped grey bars). Data expressed as mean \pm SEM. $*=p<0.05$ compared to corresponding saline treated group. 

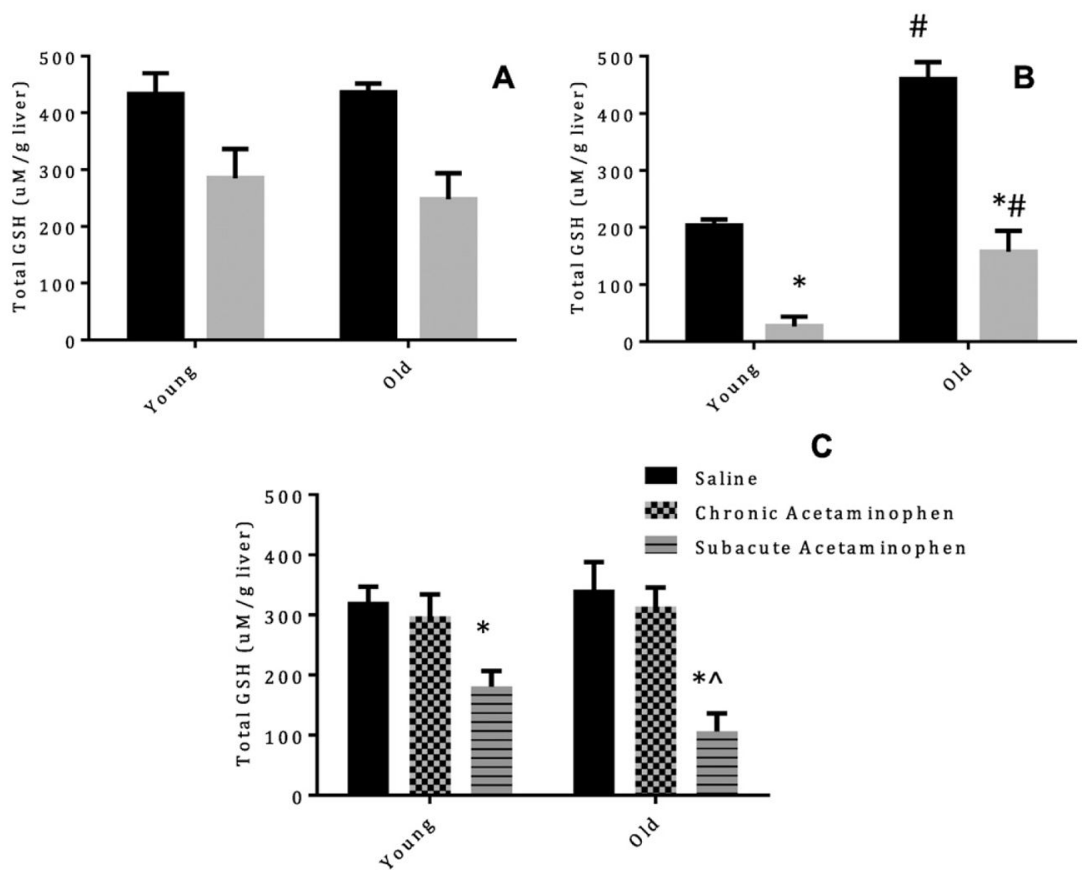

Fig. 3.

Total liver glutathione (GSH) for young and old male C57BL/6 mice from cohort 1 (A) or cohort 2 (B), $6 \mathrm{~h}$ after treatment with $300 \mathrm{mg} / \mathrm{kg}$ acetaminophen (grey bars) or saline (black bars). Data expressed as mean \pm SEM. $*=p<0.05$ compared to corresponding saline treated group. $\#=p<0.05$ compared to corresponding young group. ${ }^{\wedge}=p<0.05$ compared to age-matched chronic treatment group. 

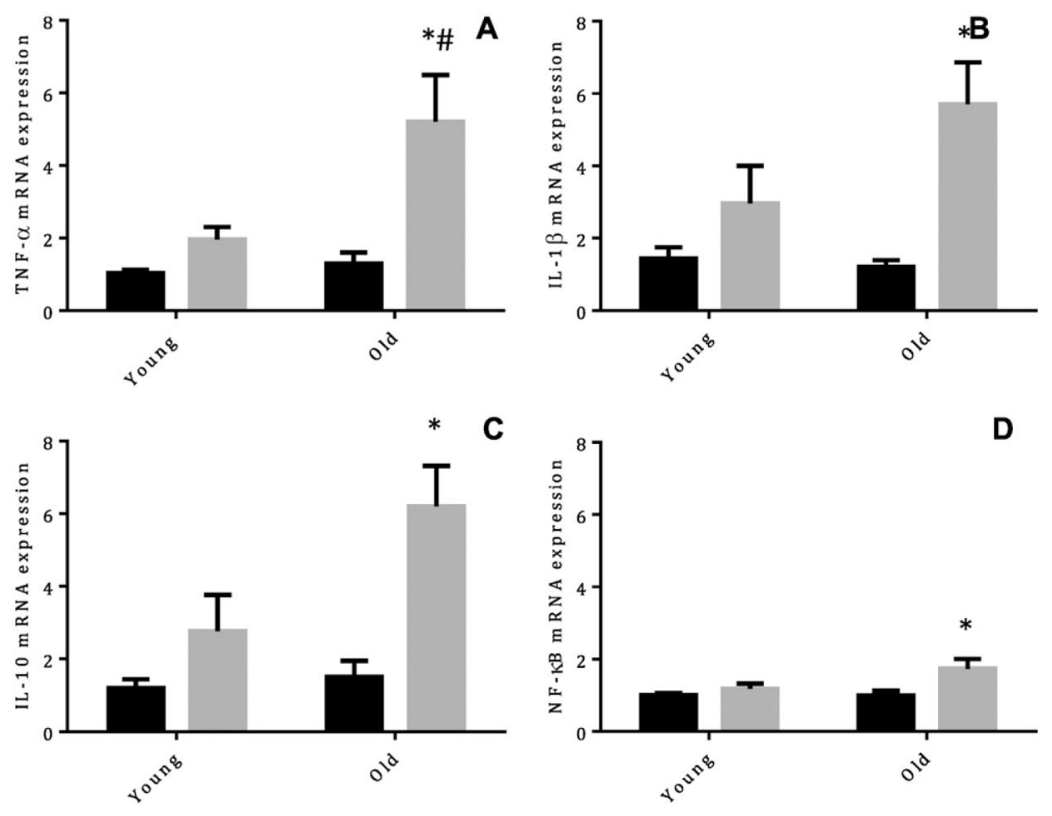

Fig. 4.

mRNA expression of inflammatory markers; (A) tumour necrosis factor (TNF)-a (B) interleukin (IL)-1 $\beta$ (C) IL-10 and (D) Nuclear factor kappa-light-chain-enhancer of activated B cells (NF- $\mathrm{kB}$ ) for young and old male C57BL/6 mice from cohort $1,6 \mathrm{~h}$ after treatment with $300 \mathrm{mg} / \mathrm{kg}$ acetaminophen (grey bars) or saline (black bars). Data expressed as mean normalized to young wild-type saline group \pm SEM. $*=p<0.05$ compared to corresponding saline treated group, $\#=\mathrm{p}<0.05$ compared to corresponding young group. 

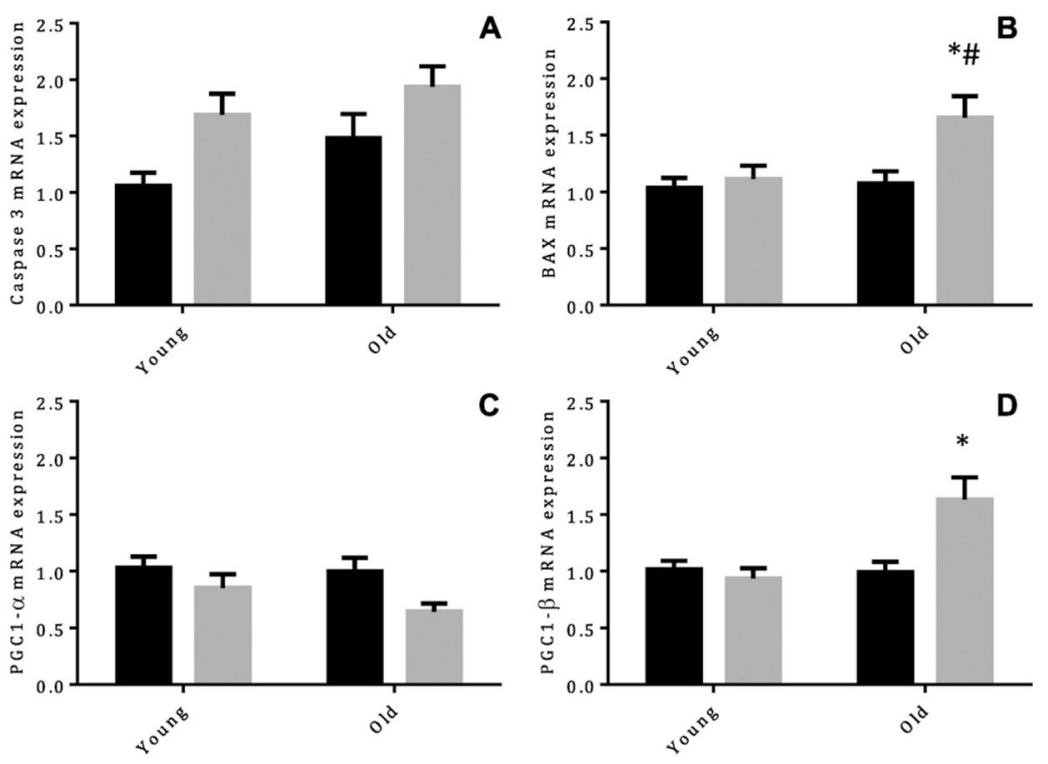

Fig. 5.

mRNA expression of (A) Caspase 3 (B) BAX (C) Peroxisome proliferator-activated receptor gamma coactivator (PGC)1- $\alpha$ and (D) PGC1- $\beta$ for young and old male C57BL/6 mice from cohort $1,6 \mathrm{~h}$ after treatment with $300 \mathrm{mg} / \mathrm{kg}$ acetaminophen (grey bars) or saline (black bars). Data expressed as mean normalized to young wild-type saline group \pm SEM. $*=p<$ 0.05 compared to corresponding saline treated group, $\#=\mathrm{p}<0.05$ compared to corresponding young group. 

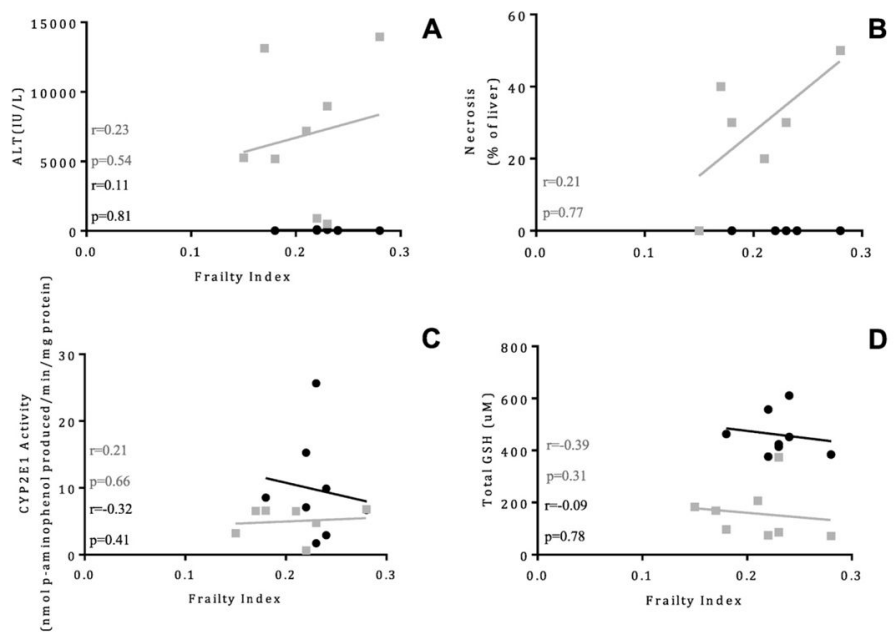

C
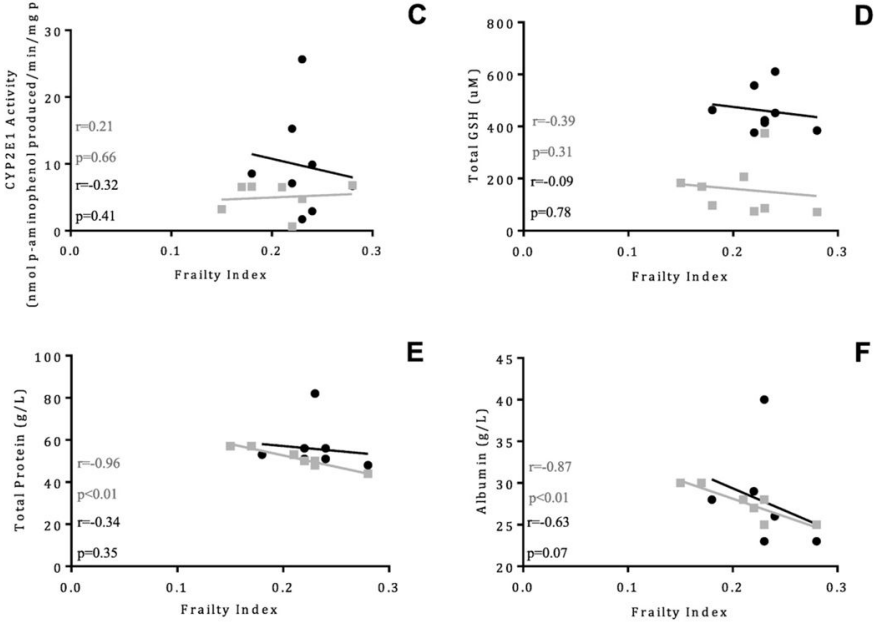

E
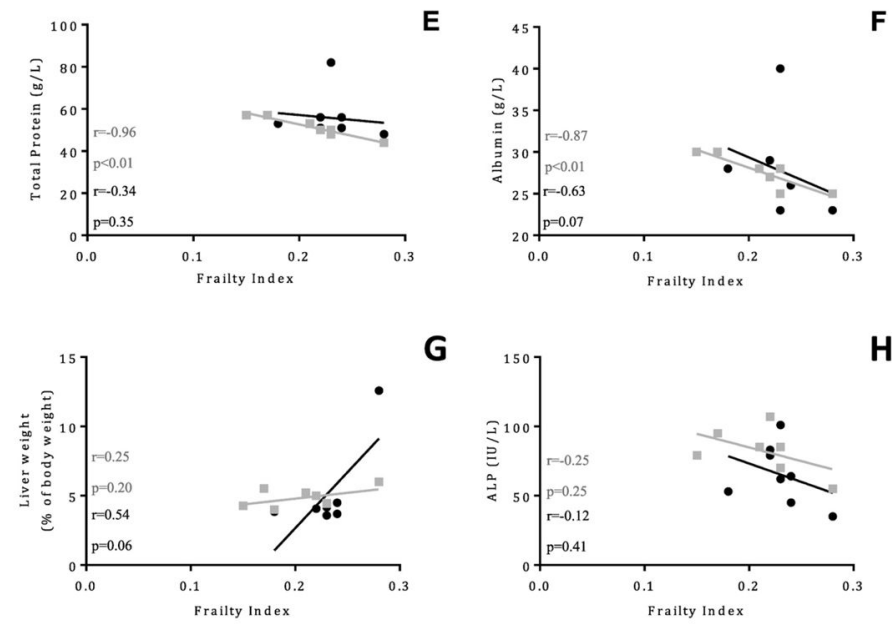

Fig. 6.

Correlation between frailty index and alanine aminotransferase (ALT), necrosis, cytochrome (CYP)2E1 activity, total liver glutathione (GSH), serum total protein, serum albumin, liver weight (as \% of body weight) and Alkaline phosphatase (ALP) for old male C57BL/6 mice from cohort 2 , treated with $300 \mathrm{mg} / \mathrm{kg}$ acetaminophen (grey) or saline (black). 

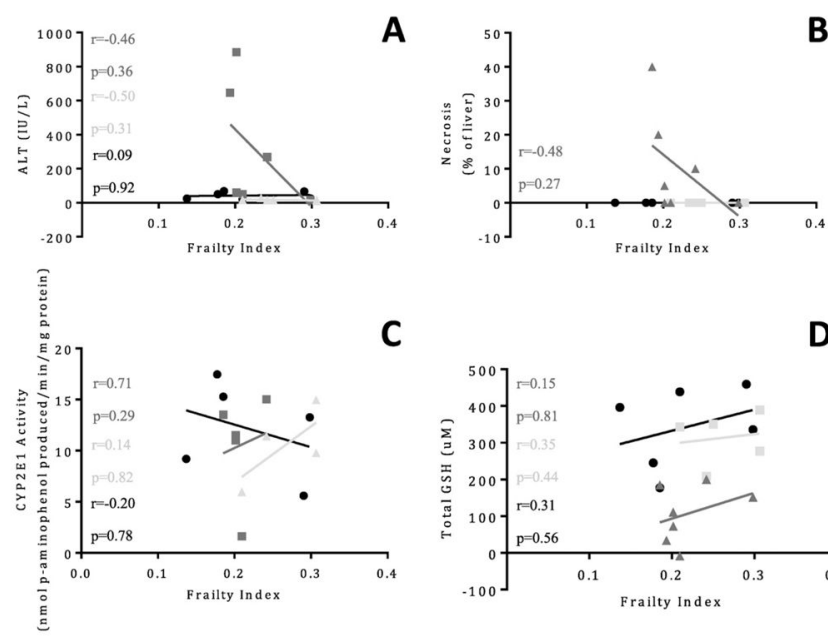

C
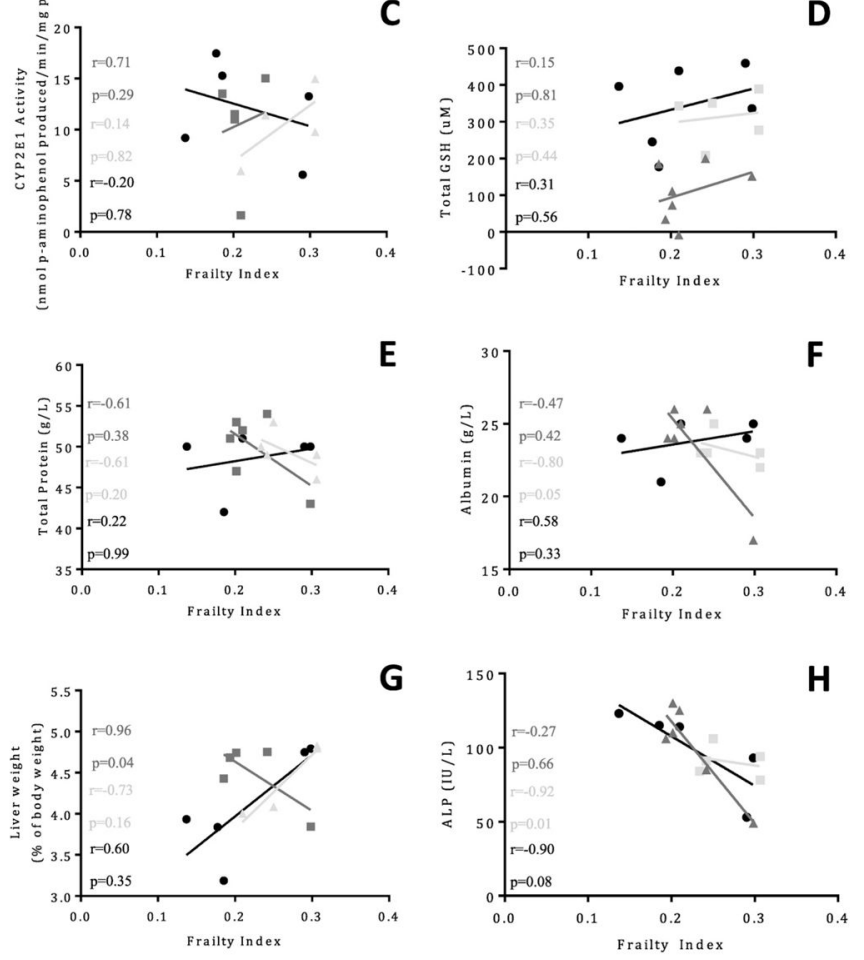

Fig. 7.

Correlation between frailty index and alanine aminotransferase (ALT), necrosis, cytochrome (CYP)2E1 activity, total liver glutathione (GSH), serum total protein, serum albumin, liver weight (as \% of body weight) and Alkaline phosphatase (ALP) for old male C57BL/6 mice from cohort 3, treated with chronic acetaminophen (light grey), sub-acute acetaminophen (dark grey) or saline (black). 


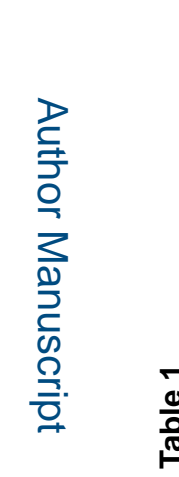



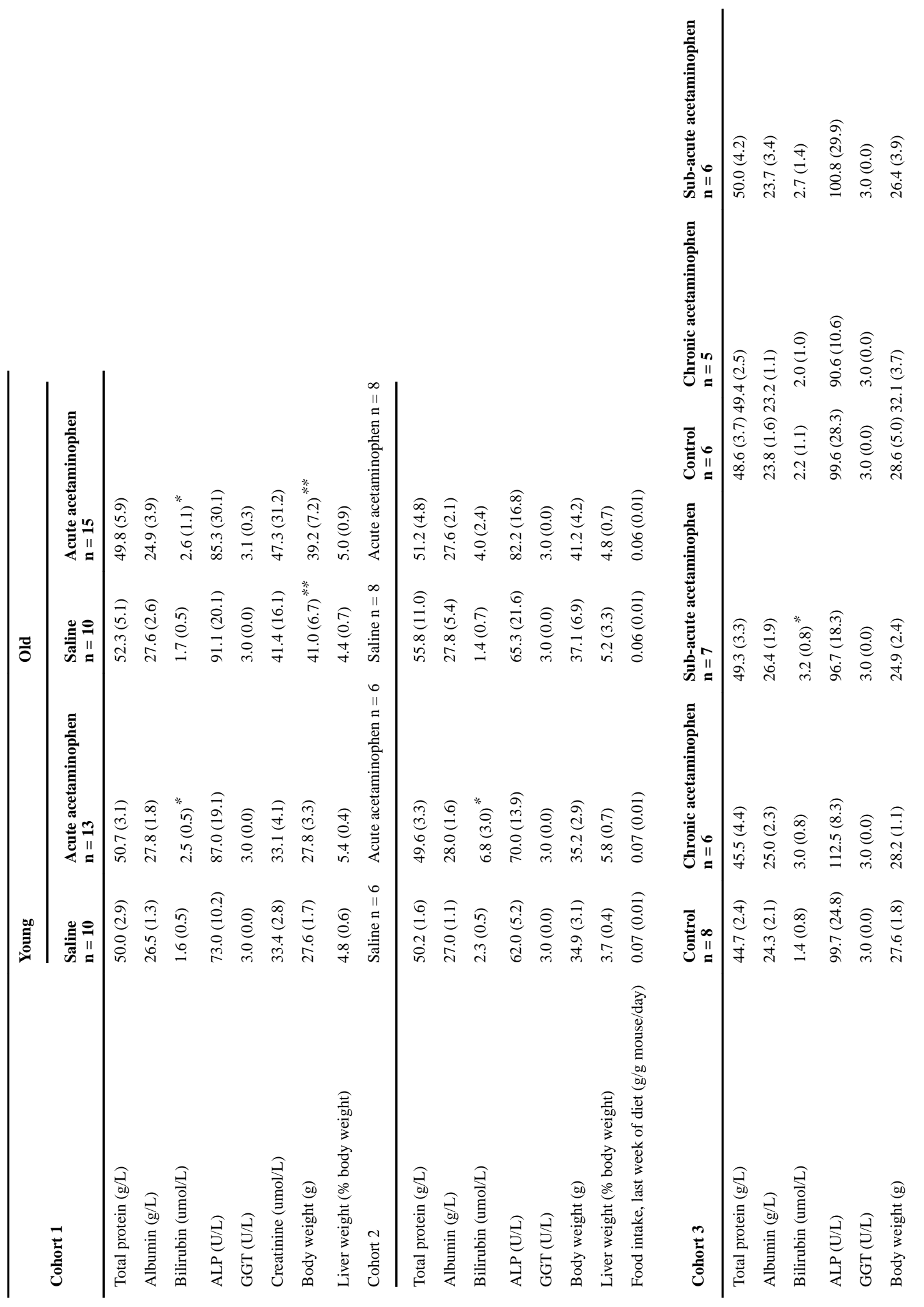

Exp Gerontol. Author manuscript; available in PMC 2018 May 30. 


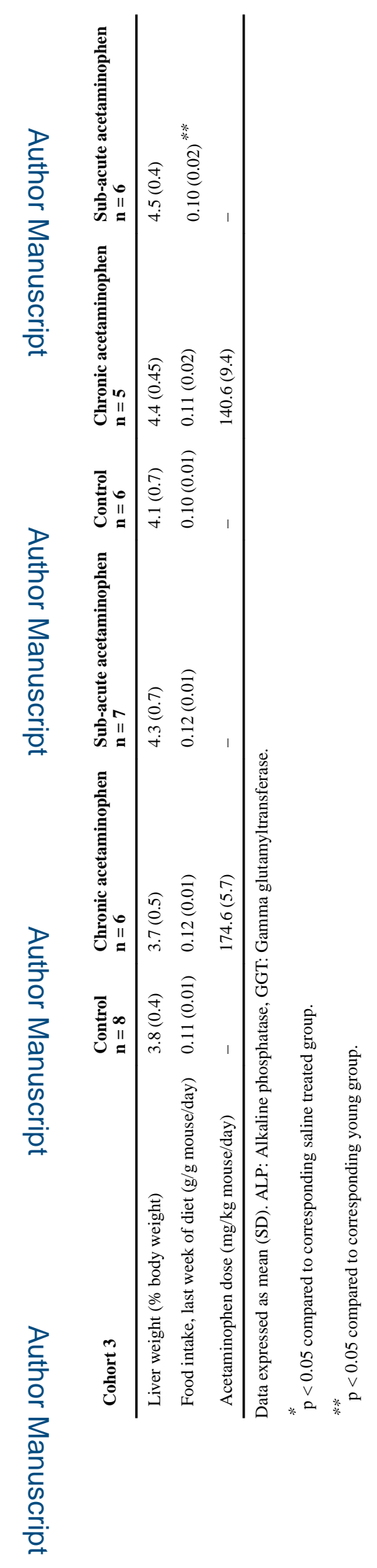

